\section{Intravitreal triamcinolone for the treatment of macular oedema}

T Pathmanathan and AC Reck
Eye (2006) 20, 1-2. doi:10.1038/sj.eye.6701802

In this issue of Eye, Ozkins and his colleagues present a paper that adds to the growing body of information on intravitreal triamcinolone as a treatment for macular oedema. This paper describes the use of intravitreal triamcinolone in chronic macular oedema in nonischaemic branch retinal vein occlusion that persists despite laser photocoagulation. Ozkins looked at 19 eyes in 19 patients with persistent macular oedema and treated these patients with intravitreal triamcinolone. A statistical improvement in visual acuity was observed with a maximal response between the first and third months following the intravitreal injection. A corresponding statistically significant reduction in macular oedema was observed.

Several papers have recently explored the use of intravitreal triamcinolone in macular oedema on the basis that corticosteroids are known to reduce inflammation and tissue oedema.

McCuen $e t a l^{1}$ studied the effects of intravitreal triamcinolone in 21 rabbits and found it to be nontoxic.

Its safety has been well documented and it has been found to be generally well tolerated by the human eye as long as the patients are followed up carefully and side effects treated when necessary. ${ }^{2}$

Many studies have shown that intravitreal triamcinolone may be a possible therapeutic modality in treating various retinal oedematous diseases.

Several authors have looked at intravitreal triamcinolone in diabetic eyes with chronic macular oedema refractory to laser photocoagulation and showed that it improved vision and reduced macular oedema in the short term. ${ }^{3,4}$ Jonas $e t a l^{5}$ found that the effect of approximately $20-25 \mathrm{mg}$ of intravitreal triamcinolone acetonide in patients with diffuse diabetic macular oedema lasted 7-8 months, returning to baseline at 9 months.

Intravitreal triamcinolone has also been tried in macular oedema following central retinal vein occlusion. Bashshur $e t a l^{6}$ looked at 20 patients with nonischaemic central retinal vein occlusions and persistent macular oedema who were treated with a single dose of $40 \mathrm{mg}$ of intravitral triamcinolone and both visual acuity and macular oedema showed a treatment benefit.

Rechtman et al ${ }^{7}$ reported the effects of intravitreal triamcinolone as an adjunctive treatment to photodynamic therapy with verteporfin in new subfoveal neovascular membranes and found that the combination was relatively safe and resulted in some improvement in lesions with some classic component.

Intravitreal triamcinolone has had mixed results in pseudophakic macular oedema. Benhamou $e t a l^{8}$ found it to improve pseudophakic macular oedema but the effect appeared to be transient.

The ocular side effects are fairly well known. Retinal toxicity does not seem to be a problem. Temporary corticosteriod glaucoma and progressive cataract formation are serious side effects but at least cataract extraction in these patients has not been found to have a markedly elevated rate of complications. ${ }^{9,10}$

Endophthalmitis is fortunately a rare side effect but it is recommended that the intravitreal injection be performed in a theatre setting. Owing to the steroid-induced immune suppression the diagnosis of an endophthalmitis may be delayed. Other rare complications that have been reported are a transient central retinal artery occlusion, conjunctival ulceration, and retinal detachment.

As in all these studies the current paper only has a relatively short follow-up time and further studies are needed to look at the long-term
Royal Eye Infirmary, Dorset County Hospital, Williams Avenue, Dorchester, Dorset DT1 2JY, UK

Correspondence: AC Reck, Tel: + 44 1305255186; Fax: + 441305255374 . E-mail: anne.reck@ wdgh.nhs.uk 
results of intravitreal triamcinolone treatment in macular oedema secondary to this and various other retinal pathologies.

\section{References}

1 McCuen II BW, Bessler M, Tano Y, Chandler D, Machemer $\mathrm{R}$. The lack of toxicity of intravitreally administered triamcinolone acetonide. Am J Ophthalmol 1981; 91(6): 785-788.

2 Gillies MC, Simpson JM, Billson FA, Luo W, Penfold P, Chua $\mathrm{W}$ et al. Safety of an intravitreal injection of triamcinolone: results from a randomized clinical trial. Arch Ophthalmol 2004; 122(3): 336-340

3 Negi AK, Vernon SA, Lim CS, Owen-Armstrong K. Intravitral triamcinolone improves vision in eyes with chronic diabetic macular ooedema refractory to laser photocoagulation. Eye 2004; September 10, [E-pub ahead of print].

4 Ciardella AP, Klancnik J, Schiff W, Barile G, Langton K, Chang S. Intravitreal triamcinolone for the treatment of refractory diabetic macular ooedema with hard exudates: an optical coherence tomography study. Br J Ophthalmol 2004; 88(9): 1131-1136.
5 Jonas JB, Kreissig I, Sofker A, Degenring RF. Intravitreal injection of triamcinolone for diffuse diabetic macular oedema. Arch Ophthalmol 2003; 121(1): 57-61.

6 Bashshur ZF, Ma'luf RN, Allam S, Jurdi FA, Haddad RS. Noureddin intravitreal triamcinolone for the management of macular oedema due to nonischemic central retinal vein occlusion. Arch Ophthalmol 2004; 122(8): 1137-1140.

7 Rechtman E, Danis RP, Pratt LM, Harris A. Intra vitreal triamcinolone with photodynamic therapy for subfoveal choroidal neovascularisation in age related macular degeneration. Br J Ophthalmol 2004; 88(3): 344-347.

8 Benhamou N, Massin P, Haouchine B, Audren F, Tadayoni $\mathrm{R}$, Gaudric A. Intravitreal triamcinolone for refractory pseudophakic macular oedema. Am J Ophthalmol 2003; 135(2): 246-249.

9 Jonas JB, Kreissig I, Degenring RF. Treatment of oedematous, proliferative and neovascular diseases with intravitreal triamcinolone. Klin Monatssbl Augenheilkd 2003; 220(6): 383.

10 Jonas JB, Kreissig I, Sofker A, Degenring RF. Intraocular pressure after intravitreal injection of triamcinolone acetonide. Br J Ophthalmol 2003; 87(1): 24-27. 